\title{
The Variables Affecting The Volatility of E-Money in Indonesia and Thailand
}

\author{
$1^{\text {st }}$ Hasdi Aimon ${ }^{1}, 2^{\text {nd }}$ Sri Ulfa Sentosa ${ }^{2}, 3^{\text {rd }}$ Moh. Ridha Mahatir ${ }^{3}$ \\ \{s3dkpl@gmail.com ${ }^{1}$, sriulfasentosa66@gmail.com ${ }^{2}$, \\ r.mahatir26@gmail.com $\left.{ }^{3}\right\}$ \\ Universitas Negeri Padang, Indonesia
}

\begin{abstract}
The study examines variables that affect the volatility of E-money in the short and long term in Indonesia and Thailand. The study used the determinants of economic growth, deposit rate, inflation, and real effective exchange rate. Quartelly data over the period 2011Q1-2019Q4 was analyzed using cointegration and the error correction model. The study found that economic growth affects the level of E-money in Indonesia and Thailand in the long term whereas in the short term, the deposit rate and real effective exchange rate affect Indonesia. Meanwhile, economic growth affects Thailand. Based on the comparison of research results, Indonesia is the best result.
\end{abstract}

Keywords: E-money, Cointegration, Error Correction Model

\section{Introduction}

Over the years, payment systems have evolved as the role of money as a means of payment changed. Along with technological developments, various non-cash payment instruments have begun to appear in other forms of payment using cards and electronic money [1]. Electronic money transactions are affected by gross domestic product, M1, and cash turnover [2]. Indonesia and Thailand are developing countries where payments are at the stage of an online payment system. This study will explain the number of E-money transactions in Indonesia and Thailand. Figure 1 shows the fluctuations in the use of E-money in Indonesia and Thailand.

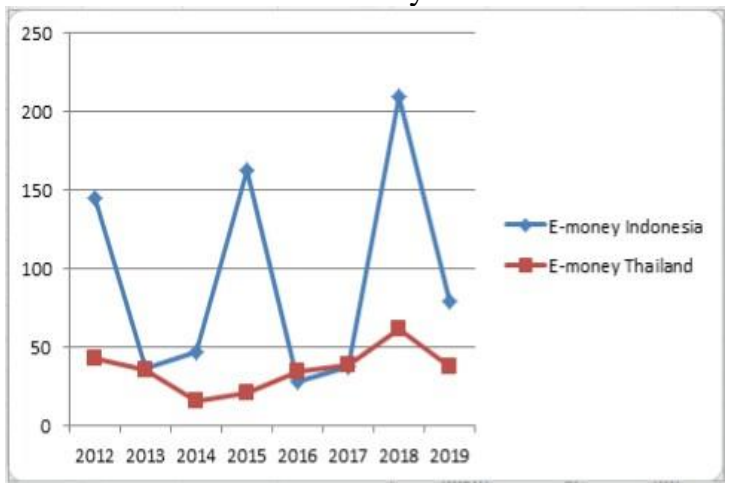

Fig. 1. E-money in Indonesia and Thailand

Based on the figure 1, the growth of E-money in Indonesia and Thailand can be seen that the growth in Indonesia is greater than Thailand. 
The study aims to analyze and explain the variables affecting the volatility of E-money in Indonesia and Thailand. It seeks to uncover the factors that trigger volatility in E-money to determine economic policy implications for governments in Indonesia and Thailand.

\section{Literature Review}

The use of electronic money has various impacts on the efficiency of payment systems and cash turnover in Indonesia. Igamo tested the variables of payment efficiency and money demand function and found that in the long term, electronic money influences increases in the level of consumption and M1 growth. The long-term analysis of the development of electronic money showed a positive and significant impact on consumption levels. Conversely, it signaled a negative and significant impact on the growth of narrow money (M1) [1]. Kartika and Nugroho analyzed electronic money and the velocity of money in ASEAN. Their study found that gross domestic product, M1, and velocity of money had a positive and significant effect on electronic money transactions [2].

Various studies have been conducted on the stability and money demand in various Asian countries. For instance, Zubaidi, Hamizah, and Masih analyzed the stability of money demand in China using a boundary testing procedure. This study confirmed that there is a stable long term relationship between M2 and its determinants: real income, inflation, foreign interest rates, and stock prices. In addition, the study found that stock prices have a significant wealth effect on long-term and short-term money demand [3]. Long and Hien focused their study on Vietnam, in the short term, exchange rates, deposit rates, interest rates on government bonds have a positive and significant effect on money demand. Meanwhile, inflation and the price of gold have no significant effect. In the long run, the price of gold, the exchange rate, deposit rates, interest rates on government bonds, and inflation have a significant effect on the demand for money [4].

Various studies on the stability of money demand. In the short run interest rate have a significant effect on the money demand [5], [6], [7], [8], [9], [10]. In the short run real income have a significant effect on the money demand [5], [11], [9]. In the short run inflation and exchange rate have a significant effect on the money demand [5], [8], [12], [13]. In the long run real income have a significant effect on the money demand [5], [7], [12], [14], [11], [15], [16], [9], [10].

\section{Methodology and Data Analysis}

This research is a de facto expo study that examines the causal relationship between economic concepts based on a country's e-money. E-money balance in Indonesia and Thailand was assessed for the period of 2011Q1-2019Q4. Variables affecting the volatility of E-money used in this study were economic growth, deposit rate, inflation, and the real effective exchange rate. Tables 1 provide a description and sources of the research data.

Table 1. Description of Variables and Data Sources for Indonesia and Thailand 


\begin{tabular}{|c|c|c|}
\hline Variable & Description & Sources \\
\hline E-money (EM) & E-money Transaction Value & $\begin{array}{l}\text { Bank Indonesia, } \\
\text { Bank of Thailand }\end{array}$ \\
\hline $\begin{array}{l}\text { Economic Growth } \\
\text { (EG) }\end{array}$ & $\begin{array}{l}\text { Real GDP based on the } \\
2010 \text { constant }\end{array}$ & $\begin{array}{l}\text { Statistics Indonesia, } \\
\text { Bank of Thailand }\end{array}$ \\
\hline Rate (R) & $\begin{array}{l}\text { Deposits rate in percentage } \\
\text { per annum }\end{array}$ & $\begin{array}{l}\text { International } \\
\text { Monetary Fund }\end{array}$ \\
\hline Inflation (INF) & Customer Price Index & $\begin{array}{l}\text { Bank Indonesia, } \\
\text { Bank for } \\
\text { International } \\
\text { Settlements }\end{array}$ \\
\hline $\begin{array}{l}\text { Real Effective } \\
\text { Exchange Rate } \\
\text { (REER) }\end{array}$ & $\begin{array}{l}\text { The relative price of the } \\
\text { currencies of two countries } \\
\text { in trading in goods and } \\
\text { services }\end{array}$ & $\begin{array}{l}\text { Bank for } \\
\text { International } \\
\text { Settlements }\end{array}$ \\
\hline
\end{tabular}

The error correction model equation model in Indonesia and Thailand can be written with the following equation:

Long-term equation:

$$
\operatorname{lnEM} M_{t}=\alpha+\beta_{0} \operatorname{lnEG}_{t}+\beta_{1} R_{t}+\beta_{2} I N F_{t}+\beta_{3} R_{E E R}+\varepsilon_{t}
$$

Where EM is e-money, EG is economic growth, $\mathrm{R}$ is deposits rate, INF is inflation, REER is the real effective exchange rate, is a residual term. $\mathrm{Ln}$ is a natural logarithmic.

Short-term equation:

$$
\Delta \operatorname{lnEM} \mathrm{M}_{\mathrm{t}}=\alpha+\beta_{0} \Delta \operatorname{lnEG_{\mathrm {t}}}+\beta_{1} \Delta \mathrm{R}_{\mathrm{t}}+\beta_{2} \Delta \mathrm{INF}_{\mathrm{t}}+\beta_{3} \Delta \mathrm{REER}_{\mathrm{t}}+\mathrm{ECT}_{\mathrm{t}-1}+\mu_{\mathrm{t}}
$$

Where $\Delta$ is the first difference operator, $E C T_{t-1}$ is the error correction models and $\mu_{t}$ is an error term satisfying noise.

\section{Research Result and Discussion}

\section{Results}

1.1. Unit root tests

The variables were tested for unit root using the ADF (Augmented Dickey-Fuller) test. The result showed that the null hypothesis of no unit roots for all variables was rejected at levels. 
The variables were stationary after the first and second differences. See Table 2 for the detailed results.

Table 2. Unit root test Indonesia and Thailand

\begin{tabular}{lllll}
\hline \multicolumn{3}{l}{ Indonesia } & \multicolumn{3}{l}{ Thailand } \\
\hline Variable & ADF & \multicolumn{3}{l}{ ADF } \\
\hline & $\begin{array}{l}\text { In the first } \\
\text { difference }\end{array}$ & $\begin{array}{l}\text { In second } \\
\text { difference }\end{array}$ & In levels & In the first difference \\
\hline EM & $-4.366^{* * *}$ & & -0.034 & $-6.036^{* * *}$ \\
EG & $-2.826^{*}$ & $-107.5 * * *$ & -0.620 & $-3.294^{* *}$ \\
R & $-2.697^{*}$ & $-6.217 * * *$ & -1.530 & $-4.414^{* * *}$ \\
INF & $-5.143^{* * *}$ & & -2.284 & $-4.749^{* * *}$ \\
REER & $-4.130^{* * *}$ & & -1.060 & $-5.705^{* * *}$ \\
\hline
\end{tabular}

Note: ADF is the Augmented Dickey-Fuller test. $* * *, * *$ and $*$ signal rejection of unit root null hypothesis at the $1 \%, 5 \%$, and $10 \%$ level, respectively.

\subsection{Long term}

The results of the long term for e-money in Indonesia and Thailand can be seen in tables 3 .

Table 3. Long term Indonesia and Thailand

\begin{tabular}{lll}
\hline & Indonesia & Thailand \\
\hline Constant & $-127.241^{* * *}$ & $-110.810^{* * *}$ \\
EG & $10.219^{* * *}$ & $8.130^{* * *}$ \\
R & -0.079 & -0.090 \\
INF & -0.064 & 0.030 \\
REER & -0.030 & 0.014 \\
Observation & 36 & 36 \\
R squared & 0.964 & 0.969 \\
\hline
\end{tabular}

\subsection{Short term} 4.

The results of the short term for e-money in Indonesia and Thailand can be seen in tables

Table 4.Short term Indonesia and Thailand

\begin{tabular}{lll}
\hline & Indonesia & Thailand \\
\hline Constant & $0.128^{* * * *}$ & $0.053^{* * *}$ \\
$\Delta \mathrm{EG}$ & 0.827 & $2.674^{* * *}$ \\
$\Delta \mathrm{R}$ & $-0.222^{* * *}$ & 0.064 \\
$\Delta \mathrm{INF}$ & 0.008 & 0.005 \\
$\Delta \mathrm{REER}$ & $-0.024^{*}$ & -0.004 \\
Observation & 35 & 35 \\
R squared & 0.245 & 0.229 \\
\hline
\end{tabular}

\subsection{F-Test}

The results of the F-test for e-money in Indonesia and Thailand can be seen in tables 5 and 6.

Table 5. F-Test Statistic Long term for Indonesia and Thailand 


\begin{tabular}{ll}
\hline Variables & F-Test \\
\hline E-money (Indonesia) & $205.0409^{* * *}$ \\
E-money (Thailand) & $238.4563^{* * *}$ \\
\hline
\end{tabular}

Table 6. F-Test Statistic Short term for Indonesia and Thailand

\begin{tabular}{ll}
\hline Variables & F-Test \\
\hline E-money (Indonesia) & $3.1699^{* *}$ \\
E-money (Thailand) & $3.0170^{* *}$ \\
\hline
\end{tabular}

\section{Discussion}

\subsection{F-Test}

Based on table 5 and 6, Long term e-money equations produced F-values of 205.0409 and 238.4563 for Indonesia and Thailand, respectively. Therefore, economic growth, real effective exchange rate, inflation, and deposit rate influence to e-money in Indonesia and Thailand. Furthermore, short term e-money equations resulted in F-values of 3.1699 and 3.0170 for Indonesia and Thailand, respectively. Thus, economic growth, real effective exchange rate, inflation, and deposit rate influence to e-money in Indonesia and Thailand.

\subsubsection{Long term}

The study proceeded to estimate long term models in Indonesia and Thailand (see Tab. 3) with E-money as the dependent variable and EG, R, INF, and REER as independent variables. The result showed that EG is statistically significant in Indonesia and Thailand based on various studies [2], [5], [7], [12], [14], [11], [15], [16], [9], [10]. This finding explains that an increase or decrease in economic growth (EG) will affect the increasing or decreasing of e-money. This is consistent with the theory of Irving Fisher (MV=PT) which explains that the demand for money is influenced by economic growth.

The coefficient of determination for e-money in Indonesia shows that the variables of economic growth, real effective exchange rate, inflation, and deposit rate contribute for 96.4 percent to e-money in Indonesia. Meanwhile, the remaining 3.6 percent is influenced by other variables not included in the e-money equation. Moreover, the coefficient of determination for e-money in Thailand is 96.9 percent, which shows the contribution of economic growth, real effective exchange rate, inflation, and deposit rate to e-money in Thailand. Meanwhile, the remaining 3.1 percent is influenced by other variables that are not included in an e-money equation.

The residuals from these models were saved and tested for stationary using the ADF test. The probabilities (0.0036) and (0.0012) were smaller than 0.05 indicating that the null hypothesis of cointegration was not rejected. Thus, the variables were stationary and cointegrated. Error correction models could, therefore, be used to estimate the short run.

\subsubsection{Short term}

The estimation of the error correction models in Indonesia and Thailand (see Tab. 4) shows that R and REER are statistically significant in Indonesia based on various studies [5], [6], [7], [8], [9], [10]. This finding explains that an increase or decrease in deposit rate (R) and real effective exchange rate (REER) will affect the decreasing or increasing of e-money. This is consistent with Baumol Tobin theory which explains that the demand for money is influenced by interest rates.. Economic growth (EG) is statistically significant in Thailand based on various studies [5], [11], [9]. This finding explains that an increase or decrease in economic growth (EG) 
will affect the increasing or decreasing of e-money. This is consistent with the theory of Irving Fisher $(\mathrm{MV}=\mathrm{PT})$ which explains that the demand for money is influenced by economic growth.

The coefficient of determination for e-money in Indonesia shows that the variables of economic growth, real effective exchange rate, inflation, and deposit rate contribute for 24.5 percent to e-money in Indonesia. Meanwhile, the remaining 75.5 percent is influenced by other variables not included in the e-money equation. Moreover, the coefficient of determination for e-money in Thailand is 22.9 percent, which shows the contribution of economic growth, real effective exchange rate, inflation, and deposit rate to e-money in Thailand. Meanwhile, the remaining 77.1 percent is influenced by other variables that are not included in an e-money equation.

The error correction terms $\left(E C T_{t-1}\right)$ are statistically significant and negative in Indonesia and Thailand.

\subsubsection{Comparison of Indonesian and Thailand's Results}

This section compares the results of the coefficient of determination, the F-test, and the Ttest. This statistical analysis uncovered that Indonesia has the best results for the E-money equations because E-money in the short term is affected by interest rates and real effective exchange rate $24.5 \%$ while in Thailand it is only influenced by economic growth and the coefficient is $22.9 \%$. In the long run E-money in Indonesia and Thailand is influenced by economic growth.

\section{Summary}

The study sought to examine variables that determine the volatility of E-money in Indonesia and Thailand. This was done using the ecometric error correction model. The study found that economic growth is statistically significant in the long term in Indonesia and Thailand. The residuals from these models were saved and tested for stationary using the ADF test. The study found that the variables were stationary and cointegrated. In the short term, deposit rate and real effective exchange rate were statistically significant in Indonesia whereas economic growth was statistically significant in Thailand. The error correction terms were statistically significant and negative in Indonesia and Thailand. Based on the comparison of research results, Indonesia is the best result.

\section{Implications/Limitations and Suggestions for Further Research}

Based on the results of this study the government or central bank Indonesia is advised to take policies that can affect E-money by controlling economic growth, deposit rate, and real effective exchange rate. The government or central bank of Thailand is advised to take policies that can affect E-money by controlling economic growth. 


\section{Acknowlegments}

This study work is supported by SIMLITABMAS (Sistem Informasi Penelitian dan Pengabdian Kepada Masyarakat) RISETDIKTI.

\section{References}

[1] A. M. F. T. A. Igamo, "The Impact of Electronic Money on The Efficiency of The Payment System And The Substitution of Cash In Indonesia," Sriwij. Int. J. Dyn. Econ. Businees, vol. 2, no. 3, pp. 237-254, 2018.

[2] V. T. Kartika and A. B. Nugroho, "Analysis on Electronic Money Transactions on Velocity of Money in Asean-5 Countries," J. Bus. Manag., vol. 4, no. 9, pp. 1008-1020, 2015.

[3] A. Zubaidi, S. Hamizah, and A. M. M. Masih, "The stability of money demand in China: Evidence from the ARDL model," Econ. Syst., vol. 33, pp. 231-244, 2009.

[4] P. D. Long and B. Q. Hien, "Determinants and Stability of Demand for Money in Vietnam," Econom. Financ. Appl., vol. 1, pp. 712-726, 2018.

[5] A. Valadkhani, "Long and Short Run Determinants of the Demand for Money in the Asian-Pacific Countries : An Empirical Panel Investigation,” J. Econ. Financ., vol. 90, pp. 77-90, 2008.

[6] O. Ben-salha and Z. Jaidi, "Some new evidence on the determinants of money demand in developing countries - A case study of Tunisia," J. Econ. Asymmetries, vol. 11, pp. 30-45, 2014.

[7] D. Nchor and V. Adamec, "Investigating the Stability of Money Demand in Ghana," Procedia Soc. Behav. Sci., vol. 220, pp. 288-293, 2016.

[8] E. Opoku, "Determinants of Money Demand in Ghana," Int. J. Acad. Res. Accounting, Financ. Manag. Scieences, vol. 6, no. 6, 2017.

[9] S. Kumar and B. B. Rao, "Error-correction based panel estimates of the demand for money of selected Asian countries with the extreme bounds analysis," Econ. Model., vol. 29, no. 4, pp. 1181-1188, 2012

[10] B. B. Rao and S. Kumar, "A panel data approach to the demand for money and the effects of financial reforms in the Asian countries," Econ. Model., vol. 26, no. 5, pp. 1012-1017, 2009.

[11] S. A. Asongu, O. E. Folarin, and N. Biekpe, "The Long Run Stability of Money Demand in the Proposed West African Monetary Union,” Res. Int. Bus. Financ., 2018.

[12] J. Dagher and A. Kovanen, "On the Stability of Money Demand in Ghana: A Bounds Testing Approach," IMF Work. Pap., 2011.

[13] A. A. Hossain, "Monetary targeting for price stability in Bangladesh: How stable is its money demand function and the linkage between money supply growth and inflation?," J. Asian Econ., vol. 21, no. 6, pp. 564-578, 2010.

[14] E. C. Nwude, K. O. Offor, and S. N. Udeh, "Determinants and Stability of Money Demand in Nigeria," Int. J. Econ. Financ. Issues, vol. 8, no. 3, pp. 340-353, 2018.

[15] X. Dou, "The determinants of money demand in China," Cogent Econ. Financ., vol. 6, no. 1, pp. $1-17,2018$.

[16] F. Jawadi and R. M. Sousa, "Money demand in the euro area, the US and the UK: Assessing the role of nonlinearity," Econ. Model., vol. 32, pp. 507-515, 2013. 